\section{Evolution and Ethics}

Nearly half a century ago Prof. T. H. Huxley, in a brilliant lecture on "Evolution and Ethics", pointed out that the view that Darwinism signifies nothing more than striving after personal or national mastery at all costs is a crude misconception of this great principle. The evolution of man himself embodies not only his physical structure but also all other attributes which have made him what he is : it involves the progressive development of standards of personal and social ethics and makes the welfare of the human race the highest purpose of the life of the individual and of the community. Material progress is only one aspect of such development, and the world is being reminded every day that it can be used as a destroying agency as well as a civilizing influence. In spite, however, of these prostituted activities, it must be acknowledged that the advance of science has, on the whole, led to the alleviation of human suffering and an increase in the capacity and the facilities for happiness. Any action-whether in peace or war-which makes degrading uses of scientific discovery and invention should be condemned by all who believe that in the evolution of man other factors are involved than those of the race to the swift and the battle to the strong. Prof. Conklin makes a most eloquent plea for the understanding of this high mission of science in the address on "Science and Ethics" delivered before the American Association for the Advancement of Science and published in the present issue of Nature. The social aspects of scientific teaching and principles were also the subject of an address on "Science and Citizenship" delivered before the Science Masters' Association on January 5. It is only by action in the spirit of these addresses that we may hope for, or expect, any advance in the ethical evolution of man himself or of civilization, which is the expression of his activities.

\section{The Services of Engineering to Mankind}

NeARLy a century ago, Dr. Samuel Smiles realized the fundamental importance to civilization of the work of the engineer and correctly estimated the interest it must have for the public. In explaining his books he wrote, "Our engineers may be regarded in some measure as the makers of modern civilisation", and he records that in a letter to him Cobden wrote, "it cannot be doubted that each succeeding generation will hold in higher estimation those discoveries in physical science to which mankind must attribute henceforth so largely its progress and improvement". These views are brought to mind by the announcement made as to its aims by the Engineering Public Relations Committee, which has recently been formed on the initiative of the Institution of Civil Engineers acting in conjunction with the leading engineering organizations in London, with Sir Clement Hindley as its first chairman. Its function is to present to the public, in suitable form, information concerning the science and practice of engineering and its service to civilization. Through the ordinary channels of information, prominence is given to the spectacular side of such undertakings as the building of the Queen Mary, the construction of the Mersey Tunnel and that of the Sydney Harbour Bridge, to mention only three great works of the last few years, but this treatment tends to obscure from public view the knowledge of the ceaseless efforts being put forth to understand more fully the works of Nature and so to harness them to the service of mankind. It is only thus that such vast undertakings can be attempted with prospect of success.

IMPROVEMENTS in the manufacture of iron and steel and other materials and in the methods of using these products to meet the changing needs of the time, advances in the design and construction of engines and machine tools, new applications of electric, hydraulic and pneumatic energy and of the refrigerating principle are but a few of the lines on which advancement is being made. At the present time, it would appear that an era of the importance of alloy metals is beginning; by their means combinations of properties are being obtained such as open up new possibilities for the engineer. With the extension of the use of metals, more and more of the work of the world comes within his province, and it is therefore most desirable that the accomplishments, purposes and possibilities of the several branches of engineering should be more fully and more generally understood. The Committee proposes by means of lectures for schools and colleges, by exhibitions, and by co-operation with the Press, the British Broadcasting Corporation and the news film companies, to get into touch with the public. Efforts will also be made to work in conjunction with engineering societies outside London and with all bodies interested in engineering. The secretary and public relations officer is Lieut.-Colonel F. H. Budden, whose address is at 1-7 Great George Street, S.W.I.

\section{Selection for Post-Primary Education}

Dr. W. P. Alexander gave a paper at a meeting in connexion with the recent conference of the National Union of Teachers to members engaged in higher education, on "Methods of Selection for PostPrimary Education". He emphasized the need for basing any system of selection on the capacity of the pupils to profit by the type of education to be followed. As at present arranged, selection is based rather on good work done in the junior school, instead of on the grounds of the child's capacity to profit by the education offered. The first most important factor is general mental energy, expressing itself primarily in words, and this ability should be the basis of selection for the grammar school type of education, or in terms of things, showing itself as practical or technical ability. In addition, however, there is required for success in life the character quality of determination. How these requirements are to be tested is a matter for research, some at least of which has already been done. Dr. Alexander suggested that the first selection need only be very simple tests in English and arithmetic, in order to know if the child has sufficient facility to begin post- 